\title{
FAMILY EXPECTATIONS ABOUT A PSYCHIATRIC INPATIENT UNIT¹
}

\author{
Gustavo Costa de Oliveira², Jacó Fernando Schneider ${ }^{3}$, Cíntia Nasi ${ }^{4}$, Marcio Wagner Camatta ${ }^{5}$, Agnes \\ Olschowsky ${ }^{6}$
}

${ }^{1}$ Paper elaborated based on the thesis - Family expectations about a Psychiatric Inpatient Unit, presented to the Programa de Pós-Graduação em Enfermagem (PPGenf) at Universidade Federal do Rio Grande do Sul (UFRGS) in 2014.

2 Master's student, PPGenf/UFRGS. Nurse, Instituto Municipal de Estratégia de Saúde da Família (IMESF). Porto Alegre, Rio Grande do Sul, Brazil. E-mail: gustavoenfufrgs@gmail.com

${ }^{3}$ Ph.D. in Nursing. Full Professor, School of Nursing and PPGenf/UFRGS. Porto Alegre, Rio Grande do Sul, Brazil. E-mail: jaco_schneider@uol.com.br

${ }^{4}$ Ph.D. in Nursing. Adjunct Professor, Universidade Federal de Ciências da Saúde de Porto Alegre and Professional Master's Program in Nursing at Unisinos. Porto Alegre, Rio Grande do Sul, Brazil. E-mail: cintianasi@yahoo.com.br

${ }^{5}$ Ph.D. in Nursing. Adjunct Professor, School of Nursing, UFRGS. Porto Alegre, Rio Grande do Sul, Brazil. E-mail: marcio. camatta@ufrgs.br

${ }^{6}$ Ph.D. in Nursing. Full Professor, School of Nursing and PPGenf/UFRGS. Porto Alegre, Rio Grande do Sul, Brazil. E-mail: agnes@portoweb.com.br

\begin{abstract}
We aimed to understand the expectations of families about a Psychiatric Inpatient Unit in the perspective of Alfred Schutz's phenomenological sociology. This is a qualitative and phenomenological research, with families of patients at a psychiatric inpatient unit of a university hospital in the state of Rio Grande do Sul, Brazil. Data were collected through phenomenological interviews, and the analysis was constructed in the light of phenomenological sociology. The results show that the expectations of the family in the Psychiatric Inpatient Unit are related to the interpretation and experiences they have in the world of everyday life; that these expectations should be valued in patient and family care; and that they may integrate the family in care for the patient. We hope to contribute so that professionals and managers reflect about the importance of understanding the expectations of families on a Unit, aiming to implement more effective health actions, based on the social relations among the subjects.
\end{abstract}

DESCRIPTORS: Psychiatric nursing. Mental health. Family. Hospitalization. sociology.

\section{EXPECTATIVAS DE FAMILIARES SOBRE UMA UNIDADE DE INTERNAÇÃO PSIQUIÁTRICA}

RESUMO: Objetivou-se compreender as expectativas de familiares sobre uma unidade de internação psiquiátrica na perspectiva da sociologia fenomenológica de Alfred Schutz. Trata-se de uma pesquisa qualitativa, de natureza fenomenológica, com 15 familiares de pacientes de uma unidade de internação psiquiátrica de um hospital universitário no sul do país. A coleta de informações deu-se entre agosto e setembro de 2013, por meio de entrevista fenomenológica, e a análise foi desenvolvida à luz da sociologia fenomenológica. Os resultados apontam que as expectativas de familiares estão atreladas à interpretação e às vivências que estes têm do mundo da vida cotidiana; elas devem ser valorizadas no cuidado ao paciente e à família; e podem integrar a família ao cuidado do paciente. Esperase contribuir para que profissionais e gestores reflitam sobre a importância de compreender-se as expectativas dos familiares sobre a unidade, visando à implementação de ações em saúde mais efetivas, pautadas nas relações sociais entre os sujeitos.

DESCRITORES: Enfermagem psiquiátrica. Saúde mental. Família. Internação hospitalar. Sociologia.

\section{EXPECTATIVAS DE FAMILIARES SOBRE UNA UNIDAD DE INTERNACIÓN PSIQUIÁTRICA}

RESUMEN: Se tuvo por objetivo comprender las expectativas de la familia acerca de una Unidad de Hospitalización Psiquiátrica en vista de la sociología fenomenológica de Alfred Schutz. Es una investigación cualitativa del tipo fenomenológico, con los familiares de los pacientes en una unidad de un hospital universitario en el estado de Rio Grande do Sul. Los datos fueron recolectados en entrevistas fenomenológicas, y el análisis se ha desarrollado a la luz de la sociología fenomenológica. Los resultados apuntan que las expectativas de la familia están relacionados con la interpretación y la experiencia que tienen en el mundo de la vida cotidiana; deben valorarse y pueden unirse a la familia en el cuidado. Se espera que contribuya a los profesionales y gestores de reflexionar sobre la importancia de la comprensión de las expectativas de estos familiares, con miras a acciones de salud más eficaces, orientados en las relaciones sociales entre los sujetos.

DESCRIPTORES: Enfermería psiquiátrica. Salud mental. Familia. Hospitalización. sociología. 


\section{INTRODUCTION}

In Brazil, care delivery to people in mental suffering and their families used to be based on the hospital-centered model, centered on care in asylums, characterized by isolation and punitive treatment, also practiced by the nursing team. ${ }^{1}$ The psychiatric reform implemented new proposals to relate with madness and the subject in mental suffering, promoting the replacement of the asylum system by a network of diversified services, such as psychiatric beds in general hospitals, Psychosocial Care Centers (PSCC), therapeutic workshops and residences, among others, aiming for the individual's reinsertion in society. ${ }^{2}$

Psychiatric inpatient units in general hospitals (UIPHG) are characterized as a care point in the mental health care network, standardized by decree 224/1992, ${ }^{3}$ which establishes the guidelines and standards for the functioning of all mental health services, and by decree $3.088 / 2011,{ }^{4}$ which establishes the Psychosocial Care Network (PSCN) for people in mental suffering and with needs deriving from the use of psychoactive substances in the context of the Unified Health System.

The psychiatric beds/units in general hospitals aim to offer a backbone in the hospital context for cases in which hospitalization is needed, after exhausting all possibilities of care in outpatient and emergency units. ${ }^{3}$ It should be highlighted that this hospitalization should be short, until the patient is clinically stable, and should be articulated with the other points in the care network. In addition, a multidisciplinary team should be involved, which works in an interdisciplinary manner. ${ }^{4}$

As a result of this change in the model that has occurred through the Brazilian psychiatric reform, the family starts to be considered as an important actor in the treatment of individuals in mental suffering. Nevertheless, the families still need further understanding and support in health services to cope with the mental suffering of their relative and to further a better family life. Therefore, investigating the expectations of family members on a psychiatric inpatient unit served as a moment to evidence the family in the treatment and to survey its mental health demands.

Hence, this study is justified by the importance of understanding the family members' motivations regarding internment at an UIPHG, granting visibility to their expectations and the possibility of the family's greater inclusion in the treatment. The research results contribute to the reflection, planning and implementation of interdisciplinary nursing care in mental health to people in mental suffering and their family members. In addition, the literature search evidences the importance of this research, as no study was found that addressed the family members' expectations on a psychiatric inpatient unit.

In this research, aiming to look at the family in a broader way and value the subjectivities, individualities, singularities and social interactions among individuals, the theoretical-methodological framework of Alfred Schutz' phenomenological sociology was adopted. According to that framework, the social realities are constructed in the meanings and identified by diving into the significant language of social interaction. In this type of approach, language, practices and things are inseparable. ${ }^{5-6}$

In view of the above, the framework of phenomenological sociology proposed in this research responds to the knowledge gap identified with regard to the family members' expectations on a psychiatric inpatient unit. This research gains relevance as it can support interdisciplinary and nursing care in mental health, contributing to interventions and the management of family members living with the mental suffering, aiming to reduce the psychological impact on the family of the relative's mental suffering.

As the psychiatric reform movement proposes valuing the family in the course of the treatment and as the paradigmatic change may mean a process of (re)thinking actions in the mental health area, the goal in this research was to understand the family members' expectations on a general UIPHG from the perspective of Alfred Schutz' phenomenological sociology.

\section{METHOD}

A qualitative and phenomenological research was developed, involving family members of patients at a Psychiatric Inpatient Unit of a general hospital in Rio Grande do Sul, Brazil.

In this study, the theoretical-methodological framework of Alfred Schutz' phenomenological sociology was used, which allowed us to understand the experiences of patients' family members at a psychiatric inpatient unit of a general hospital regarding these relatives' expectations. In this reference framework, the researcher understands the family members based on their experiences and the meanings attributed to them. ${ }^{5}$ 
Thus, the phenomenological sociology aims to give voice to the people, considering their experiences, interpretations of the world they live in, with a view to unveiling the essence of the phenomenon under investigation. This permits understanding the phenomenon in its intersubjective meaning, that is, based on the social relationships. ${ }^{5}$

The phenomenological sociology evidences the subject as an actor of the action, capable of describing what is intended with a certain action, representing a possibility to think, support and develop the research and care action in Nursing. ${ }^{6}$ To understand the phenomenon, the subject's intersubjective dimension needs to be valued, his/ her experiences and conscious actions and, hence, his intentions and expectations. ${ }^{5}$ Nevertheless, the description should be natural, exploring what is given about the thing that is perceived, thought, discussed, avoiding any hypotheses, merely expressing what the subject presents. ${ }^{7}$

The expectations explored in this study refer to what the family members expect on the psychiatric inpatient unit, their interests, that is, in line with Schultz' reference framework, the "because-motives" of their actions. The "becausemotives" are the motives for which the action was developed, which are future-oriented. ${ }^{5}$

The convergence of the family members' network of motivations in seeking care for their relative in mental suffering permitted characterizing what is typical in this group's action, ${ }^{5}$ that is, the typical characteristics of the social actions these patients' family members perform with regard to the psychiatric internment at the general hospital, revealing what they tend to expect from this service.

Fifteen family members were interviewed of patients who were hospitalized at the psychiatric internment unit of a general hospital. The inclusion criteria were: being 18 years old or older; living in the same house as the patient; accompanying the patient during family members' visit to the hospital and being considered a relative by the patient. The number of interviewees in the study was decided in the course of the data collection, which was terminated when, through the reading and interpretation of the discourse, it was perceived that the phenomenon had been revealed in its essence. The information collection period ranged from August till September 2013.

To collect information, phenomenological interviews were held with the family members. The phenomenological interview takes the form of situated existence in the meeting for the intuitive understanding of the experience, with a view to accessing the experiences of the social world and represents a way for the subject to truly penetrate his / her existence. ${ }^{6,8}$ For the interviews, the following guiding question was used: "What are your expectations on the psychiatric inpatient unit?".

The collected information was submitted to phenomenological analysis in line with the reference framework of Alfred Schutz' phenomenological sociology. To unveil the essence of the phenomenon, the following steps were followed: ${ }^{9}$ attentive reading of the statements to capture the situation experienced and the subjects' becausemotives; identification of concrete categories that cover the subjects' acts; rereading of the statements to select and group excerpts that contained similar significant aspects of the subjects' actions; finally, based on the typical characteristics of the statements, we established the meaning of the subjects' actions, aiming to describe what its typical in the family members' action.

Based on the convergences among the units of meaning that emerged from the statements, this information was analyzed in the light of Schutz' reference framework and, next, the results of the relatives' experiences were organized in three concrete categories: the improvement of the patient's health condition; family care and the treatment as a qualified care project and action. In this article, the two concrete categories are presented regarding the family members' expectations on a psychiatric inpatient unit: the improvement of the patient's health condition and family care.

These categories were analyzed through comprehensive interpretation, aiming to observe the things without practical interest in judging what one was observing, but in considering the facts, the result of the interpretation being the phenomenon as the subject experienced it.

The testimonies were identified using letters " $\mathrm{F}$ " and ordinal numbers from one to 15 , preserving the subjects' anonymity. The researchers took care to conduct the phenomenological interview, listening to the participants without critical sense of judgment and interacting with them in a comprehensive approach.

In this research, the requirements set in National Health Council Resolution 466/2012 regarding compliance with ethical aspects were complied with. Approval was obtained from the Institutional Review Board at the Hospital de Clínicas de Porto Alegre, under opinion 331.493/2013. 


\section{RESULTS AND DISCUSSION}

Based on the analysis of the testimonies in the light of Alfred Schutz' phenomenological sociology, the two concrete categories in the family members' expectations are presented: improvement of the patient's health condition and family care.

\section{Improvement of the patient's health condition}

Each human being can only be understood based on his biography, that is, his situation not only in terms of the physical space and the external time or his role in the social system, but also his moral and ideological position. ${ }^{5}$ In view of the above, it is observed that the family members' biographical situation is permeated by the desire for improvement in the patient's health condition, with the consequent discharge from the Psychiatric Inpatient Unit and, in addition, by other elements like family care. Therefore, it is relevant to reflect on the family members' biographical situation, considering the aspects related to the patient's health condition, which plays a distinctive role in the configuration of these family members' expectations.

In the family members' statements, initially, it was observed that they note that the patient, a relative, gains a better health at the Unit, and they also want the patient to return to the family group in a better health condition: [...] I obviously hope she'll get out better, I already feel that she's better. [...] She's being well taken care of, I think she'll come home better, I hope the clinical part will also improve (F1).

[...] I hope he [...] gets better, because he's been here for quite some time and things do not go very fast, as his disease is very complicated. But I hope he'll get better and that he'll get out of here much better (F8).

I hope [...] she'll get out much better than she was. I want her to get out well. I expect her to get out of here well, very well (F11).

The reports reveal that the patient's internment at the unit represents an important point of care for the relatives, as it permits monitoring in mental health at the service. Through this type of care, the family members aim to improve their relative's health condition and for that person to be discharged from the psychiatric inpatient unit in better health conditions than at the time of his internment.

In addition, the family members appoint the desire that, upon their relatives' discharge from the inpatient unit, their relatives may be able to return to their daily activities, which were compromised thus far, taking hold of the aspects of their life more autonomously. Therefore, it is considered elementary for the patients to be able to rule their own lives and recover their social functioning, developing personal actions as observed in the statements: I want her to get out of here, to be able to cope with her life and does not allow herself to get into the condition she got into (F10).

[...] he'll be able to [...] recover a range of aspects in his life that used to be quite compromised (F4).

His emotional control because he's a person who, no matter how much he tells you that he's well, often he's not. [...] I hope he'll be able to control himself, live well, live healthily (F13).

[...] we always expect [...] her to be able to live a normal life, [...] cope with the daily reality of her house, of being able to go out and have fun, being together with her relatives too. [...] The main expectation is that she'll be able to live her life, do things (F14).

The statements evidence the family members' desire for their relatives to be able to lead a more autonomous life in the post-discharge period. Hence, they expect that, when their symptoms improve, the patients will be able to actively take hold of their life and their exercise of citizenship.

The statements also revealed that, when the family members are confronted with the psychiatric internment of their loved one, they consider it is fundamental to recover the patients in terms of the way they operate their life, ranging from the simplest to the most complex aspects. This perception should gain further visibility at the UIPHG, so that the health team tries to develop mental health actions that favor the continuous construction of autonomy and co-accountability in the course of the therapeutic process, promoting the transformation of the social reality, based on the subjects' context.

Nevertheless, the responsibilities for this construction should be shared among the care points in the mental health care network, because the psychosocial care network recommends that psychiatric inpatient care at general hospitals be articulated with the Singular Therapeutic Project (STP) developed by the users' referral service. ${ }^{4}$ In other words, the other points in the network the user has most contact with (the Family Health Strategy, the primary health care service, the Psychosocial Care Centers, the therapeutic homes etc.) should produce and operate an STP that attends to the user's needs. Nevertheless, these study results 
suggest that this articulation is still incipient at the service studied, as no manifestations of this type of work are perceived in the relatives' statements.

The family members of subjects in mental suffering in inpatient services usually experience difficulties in their daily life as a result of crisis situations and the continuity of their relatives' treatment, which often makes them intern the patients. Nevertheless, they also expect the improvement of their relatives, considering the individual's context and care beyond the hospitalization. ${ }^{10}$

When considering the context these subjects are inserted in, the daily life of each subject and the therapeutic offering of quality of life at the service, the transcendence of values, practices and feelings accumulated over time is favored. ${ }^{11}$ Therefore, seeking a better quality of life in the post-discharge period becomes important to allow the patients to share the daily life world with their peers, experience and interpret this world all of them have in common, as noted in the following statement: quality of life, I mean, that he wants to do things. Like, that he wants to play with his children, to go out, that he doesn't want to just lie down, that he doesn't want to stay prostrated as he used to (F2).

As observed, the patients' desire to and practice of occupational activities, from the family members' viewpoint, can represent daily quality of life. These activities can help them to minimize the mental suffering through pleasant times and, in the socialization, as these patients' social interaction with the family and other subjects can be strengthened.

Therefore, it is identified that, based on the psychosocial care model, particularly the care offered in services like psychiatric inpatient units and beds in general hospital, the patients' daily reality is modified, from a daily life that proposed the patients' isolation and segregation to a daily life that favor the qualitative recovery of life and social reinsertion.

In that perspective, the creation of services to replace the asylum model emerges as a support and alternative for subjects in mental suffering, as these devices are specialized, offering specific care and aiming for the patients' social reinsertion and the promotion of their inclusion in society. ${ }^{12}$

Therefore, in the mental actions, essential aspects of social interaction need to be considered, as described in Schutz' reference framework, ${ }^{5}$ such as intersubjectivity, the presentation of the other, the sharing of a communicative environment and the reciprocity of perspectives.
The family members also find the patient's cure important in the outcome of the therapeutic process, as expressed in the statements: the main expectation, [...] is that he'll be cured. For me, the cure is to erase, to completely annul the motive why he got into this state of depression that increased over the years of his life (F6).

Getting out cured is the greatest happiness in the world. I really hope [...] for her cure. I want her to get out of here cured, because we're already tired of hospital (F3).

Now she's amidst people who take care of her, yes, I expect her to get cured and get well (F11).

[...] I expected my son to get out of here well, that he'll get cured. It's better here [...] but I hope he won't return (F12).

The statements reveal the patient's cure as an element of the family members' biographical situation, as they interpret and share the world based on their situation. Thus, the relative visualizes the possibility of cure through his/her values and beliefs, which integrate and drive this relative's understanding of the daily life world.

For society and particularly the family to be able to cope with the different forms of mental suffering, the health system needs to see it unprejudiced, simply considering the conditions as a human being, abandoning the conception of cure and adopting an expended care concept. ${ }^{13}$

From the perspective of psychosocial care, the goal of the interdisciplinary care actions is focused on the need for social inclusion of people with mental disorders. Hence, the perspective changes to other aspects of the individual's life and biological, social and economic needs. The target of the interventions is no longer cure, but the exercise of social exchanges. ${ }^{14-15}$

The testimonies express the family members' expectations on what can be obtained based on mental health care in its current configuration. According to the relatives, the psychiatric inpatient unit offers care to the patient and, in that situation he was in, shows to be the best alternative in comparison with other health services, which can entail expectations of cure.

The human being projects future experiences based on different types of past experiences that express reliable expectations for the future. ${ }^{5} \mathrm{In}$ that sense, the family members express the hope of cure based on the reliability and stability acquired in the external world, in the case the psychiatric inpatient unit. 
Throughout the construction of this category, the health condition of patients at the psychiatric inpatient unit is characterized as a component highlighted in the family members' daily life. In addition, within this component, these signal the desire for their family member to me discharged better, cured or having quality of life.

\section{Family care}

Family care is established in the family members' daily life world and is shared among peers, experienced and interpreted by all social actors involved in the care process. This is not a subject's private world, but also the environment of all, in which both are elements of one another's biographical situation. ${ }^{5-6,9}$

The person lies within the reach of my (who's that person talking her?) direct experience when (s)he shared a spatial and temporal community with me. Based on the people within the reach of one another's experience, the face to face situation is constituted, which is the social relationship directly experienced. ${ }^{5}$

Thus, it is observed that the understanding of the social world with the others in its intersubjective meaning is achieved through the social relationship among the subjects. This illustrates the importance of understanding the family members (their subjectivity) and their context (history and relationships), to the extent that family members' expectations about an UIPHG are linked to family care and derive from the situation these family members experience.

The family members' expectations include family care. Hence, what they expect from the psychiatric inpatient unit is to get team care, as this family may be strengthened by its relative's mental suffering and therapeutics.

She's in good hands, I say that the team is paying attention to the family members, I think it is important and you feel confident. The mere fact that the person pays attention to the patient and the patient's relative, that's already something extraordinary (F5).

[...] that is very important, good impression, this interest the professional transmits to the relative, mainly the closest and responsible relative, a natural interest (F7).

Attention is something basic that seems like nothing in daily life, but you get out of here feeling happy, We all need to pay attention somehow (F15).
According to the family members, family care in the health practices at the psychiatric inpatient unit is considered elementary, as an environment needs to be constituted that helps the family to cope with its relative's mental suffering. Therefore, it is important to promote spaces to pay attention to the family in the substitutive mental health services, also granting visibility to their needs and life context. ${ }^{15-16}$

The family members' daily life world refers to the complete sphere of each subject's experiences, which is circumscribed by objects, persons and events he faces when accomplishing the pragmatic objectives of life. It is a world in which the person is fully awake and that imposes itself as the main reality of his life. ${ }^{5}$

In the family members' life world, singularities and subjectivities are constructed, which outline the understanding of the experience of madness. Hence, considering that each subject will individually interpret the family member's mental suffering, expectations like family care should be valued in family care. Thus, the subjective dimension of the family turns into the main challenge in health work as, based on this dimension, the professionals need to acknowledge and respect, through an intersubjective relationship, expectations and meanings that derive from the singularity of each subject. ${ }^{9}$

The intersubjective relationship, as a family care action, also represents an elementary action in the work of the UIPHG team when the family members report, as a form of expectation, that the Unit should offer monitoring to the family, according to the following statements: I think there should be monitoring for the family members (F1).

[...] I feel like, we need to talk to the other, sit, understand what the person is saying, and I expect that with regard to the professionals (F3).

These statements evidence the family members' desire to be monitored by the unit's health team, revealing the importance of spaces of listening, welcoming, bonding, which permeate the social relationships among the subjects involved in the health care process.

The search to strengthen the social relationships in the family care sphere reflects the possibility to give voice to these family members, understand their history, understand their context, visualize their expectations, experiences and, in parallel, further their understanding and construction of the health actions developed at the unit. 
In short, this allows the relatives to enhance the exchange of experiences with the professionals and other families, deciding and negotiating their actions in the daily life world with these social actors.

In that sense, some relatives also expressed their expectation about the UIPHG in the interviews regarding the family members' involvement in care for mental patients, as observed in the following statements: something else which I think is very interesting is to engage the patients' family members [...] in the treatment. Then you call the family and explain (F1).

[...] I find that family meeting important. [...] You get out as another person, because we witness the other person's experience who has gone through or is going through the same thing, and being able to share that experience (F5).

The social interaction established among the subjects in the mental health care process can facilitate the family members' engagement in the patients' treatment. The statements reveal that this engagement is linked to the family members' participation in the patient's treatment. The statements reveal that this engagement is linked to the family members' participation in family meetings and health actions at the unit. Through this sharing with the other social actors, these family members can enhance their understanding, interpretation and experiences regarding their situation and that of their hospitalized relative.

The family constitutes the elementary resource to promote the patient's psychosocial rehabilitation. Therefore, it is fundamental for the services to offer support and training processes to the families, aiming to incorporate the family members into the therapeutic and rehabilitation proposals, according to the proposals of the psychosocial care paradigm. ${ }^{17}$

Nevertheless, work with the families requires that the team adopt a perspective of acting together and not intervening in the family. This approach is important in the search to put the psychosocial care mode in practice, which is committed to the psychosocial rehabilitation and social reinsertion of people in mental suffering. ${ }^{18}$

In addition, some family members put forward, as their expectation about the psychiatric inpatient unit, to obtain information about the patient's situation at the unit, according to the following reports: when I call everyone readily sees to me, and if the person does not feel capable of giving me information, (s)he passes me on to who is (F1).
I am talking about my expectation that each time I returned here the people attended to me with great education and gave me the answers (F9).

I hope and I am satisfied with her treatment, with the team's return with the patient and with the family, because the family needs this (F5).

It is observed that the family members reveal that they obtain information from their relatives by telephone or in face-to-face contact with the unit team, evidencing the consolidation of these expectations in this health service's practices. As observed, this health action can strengthen this family's bond with the team, minimize these relatives' suffering, facilitate the family's insertion in care for the patient, besides furthering the understanding and interpretation of this family with regard to the therapeutic space.

Mental patients can present difficulties in terms o autonomy and social integration, which can influence the family dynamics. ${ }^{19}$ Changing a care logic in mental health that advances towards these families' non-exclusion is impossible without offering support and advice to the families. In that sense, it is important for these family members to have clear, up-to-date and conscious information from the patient, besides the reality of the health service, how it works, what its objectives are and the composition of the health team, in order to understand the health actions. ${ }^{17}$

The phenomenological analysis permitted understanding the expectations related to the importance of family care, as the social interactions between family and professionals can strengthen these family members in view of the mental suffering of their relative. The family members mentioned family care as an expectation, which permits evidencing their social context.

Some family members also mentioned expecting their monitoring and involvement in the patient's treatment, helping them to cope with the mental suffering, inside the unit and at home/ community. In addition, they expressed expectations regarding how to obtain information, which is fundamental to understand and interpret their own and the patient's situation.

Through the comprehensive interpretation of the two concrete categories in the understanding of the family members' expectations on an UIPHG, what is typical of this social group's action was constructed. This typical part comprises these family members' motivations, granting a meaning to their expectations. The convergence of 
the "because-motives" of a certain action, which is shared among the people living the same phenomenon, permits characterizing what is typical in the stakeholders' action. ${ }^{5,9}$

The family members expect that, through the care of the team at the psychiatric inpatient unit, the patient's health condition will improve, as they want their relatives to leave the unit better, cured and having quality of life, thus minimizing this patient's mental suffering. In addition, the family members expect family care, as they mention the desire to get information from their relative, as well as the family's monitoring and involvement in the patient's treatment, and to receive attention and care by the unit team, promoting the mental patient's greater insertion in care.

\section{FINAL CONSIDERATIONS}

This study reveals that an UIPHG that presupposes its mental health actions in the psychosocial mode needs to establish health practices focused on the family, considering the family members' expectations on the Unit. Thus, looking at the relatives with a view to apprehend their experiences in the daily life world can represent an important element for the consolidation of psychosocial care.

Hence, we could reflect on the social relationships constituted among the subjects involved in the care process, in view of the meanings each subject attributes to the experiences in the daily life world. It is while weaving the relationships with the other that the nurses can take hold of their experiences and expectations, establishing health actions together with/starting from the other, and not on the other.

What is typical about the family members' action in this study reveals that their expectations are common to most families who have a relative hospitalized at the UIPHG and who share the same beliefs and social values, and should therefore be assessed by managers, mental health and nursing professionals in order to respond to the health needs these family members expressed.

When encouraging professionals and health managers to reflect on the relatives' expectations, more effective mental health practices may be planned and implemented, based on the social relations among the subjects, and which permit the transformation of the social reality.

\section{REFERENCES}

1. Almeida Filho AJ, Moraes AEC, Peres MAA. Atuação do enfermeiro nos Centros de Atenção Psicossocial: implicações históricas da enfermagem psiquiátrica. Rev RENE. 2009 Abr-Jun; 10(2):158-65.

2. Berlinck MT, Magtaz AC, Teixeira M. A Reforma Psiquiátrica Brasileira: perspectivas e problemas. Rev Latino-Am Psicopatol Fundam. 2008; 11(1):21-7.

3. Ministério da Saúde (BR), Secretaria Executiva. Secretaria de Atenção à Saúde. Legislação em Saúde Mental: 1990-2004. Brasília (DF): MS; 2004 [acesso 2013 Nov 15]. Disponível em: http:/ / bvsms.saude. gov.br/bvs/publicacoes/legislacao_mental.pdf

4. Ministério da Saúde (BR), Portaria n. 3.088, de 23 de dezembro de 2011. Institui a Rede de Atenção Psicossocial para pessoas com sofrimento ou transtorno mental e com necessidades decorrentes do uso de crack, álcool e outras drogas, no âmbito do Sistema Único de Saúde. Brasília (DF): MS; 2011 [acesso 2013 Nov 23]. Disponível em: http:/ / bvsms.saude.gov.br/bvs/saudelegis/gm/2013/ prt3088_23_12_2011_rep.html

5. Wagner HTR, organizador. Sobre fenomenologia e relações sociais / Alfred Schutz. Petrópolis (RJ): Editora Vozes; 2012.

6. Jesus MCP, Capalbo C, Merighi MAB, Oliveira DM, Tocantins FR, Rodrigues BMRD, et al. A fenomenologia social de Alfred Schutz e sua contribuição para a enfermagem. Rev Esc Enferm USP. 2013 jun; 47(3):736-41.

7. Sokolowski R. Introdução à fenomenologia. $3^{\mathrm{a}}$ ed. São Paulo (SP): Loyola; 2012.

8. Carvalho MDB, Valle ERM. A pesquisa fenomenológica e a enfermagem. Acta Sci., Health Sci. 2002; 24(3):843-7.

9. Camatta MW. Ações voltadas para saúde mental na Estratégia de Saúde da Família: intenções de equipes e expectativas de usuários e familiares [tese]. Porto Alegre (RS): Universidade Federal do Rio Grande do Sul. Programa de Pós-Graduação em Enfermagem; 2010.

10. Mello RM, Schneider JF. A família e a internação psiquiátrica em hospital geral. Rev. Gaúcha Enferm. 2011; 32(2):226-33.

11. Jorge MSB, Pinto DM, Quinderé PHD, Pinto AGA, Sousa FSP, Cavalcante CM. Promoção da saúde mental - tecnologias do cuidado: vínculo, acolhimento, co-responsabilização e autonomia. Cien Saude Colet. 2011; 16(7):3051-60.

12. Guedes AC, Kantorski LP, Pereira PM, Clasen BN, Lange C, Muniz RM. A mudança nas práticas em saúde mental e a desinstitucionalização: uma revisão integrativa. Rev Eletr Enf [Internet] [online]. 2010 [acesso 2013 Mai 15];12(3):547-53. Disponível em: http:/ / www.fen.ufg.br/fen_revista/v12/n3/ v12n3a19. 
13. Amarante AL, Lepre AS, Gomes JLD, Pereira AV, Dutra VFD. As estratégias dos enfermeiros para o cuidado em saúde mental no programa saúde da família. Texto Contexto Enferm. 2011 Jan-Mar; 20(1):85-93.

14. Leão A, Barros S. As representações sociais dos Profissionais de Saúde Mental acerca do Modelo de Atenção e as possibilidades de inclusão social. Saúde Soc. 2008; 17(1):95-106.

15. Mielke FB, Kohlrausch E, Olschowsky A, Schneider JF. A inclusão da família na atenção psicossocial: uma reflexão. Rev Eletr Enferm [online]. 2010 [acesso 2013 Jun 23]; 12(4):761-5. Disponível em: http:// www.revistas.ufg.br/index.php/fen/article/ view/ 6812

16. Bessa JB, Waidman MAP. Família da pessoa com transtorno mental e suas necessidades na assistência psiquiátrica. Texto Contexto Enferm [online]. 2013 [acesso 2013 Jun 23]; 22(1):61-70. Disponível em http:/ / www.scielo.br/scielo.php?pid=S010407072013000100008\&script=sci_arttext\&tlng=pt

17. Dimenstein M, Sales AL, Galvão E, Severo AK. Estratégia da Atenção Psicossocial e participação da família no cuidado em saúde mental. Physis. 2010 Dez; 20(4):1209-26.

18. Camatta MW, Schneider JF. A visão da família sobre o trabalho de profissionais de saúde mental de um Centro de Atenção Psicossocial. Rev Enferm Esc Anna Nery. 2009; 13(3):477-84.

19. Sant'Ana MM, Pereira VP, Borenstein MS, Silva AL. O significado de ser familiar cuidador do portador de transtorno mental. Texto Contexto Enferm. 2011; 20(1):50-8. 